\title{
ADSORPTION OF Pb AND Cd ONTO METAL OXIDES AND ORGANIC MATERIAL IN NATURAL SURFACE COATINGS AS DETERMINED BY SELECTIVE EXTRACTIONS: NEW EVIDENCE FOR THE IMPORTANCE OF Mn AND Fe OXIDES
}

\author{
DEMING DONG ${ }^{1}$, YARROW M. NELSON ${ }^{2}$, LEONARD W. LION $^{2}$, MICHAEL \\ L. SHULER ${ }^{3}$ and WILLIAM C. GHIORSE ${ }^{4}$ \\ ${ }^{1}$ Department of Environmental Science, Jilin University, Changchun 130023, People's Republic of \\ China; ${ }^{2}$ School of Civil and Environmental Engineering, Cornell University, Ithaca, NY 14853, USA; \\ ${ }^{3}$ School of Chemical Engineering, Cornell University, Ithaca, NY 14853, USA and ${ }^{4}$ Section of \\ Microbiology, Cornell University, Ithaca, NY 14853, USA
}

\begin{abstract}
Surface coatings (biofilms and associated minerals) were collected on glass slides in the oxic surface waters of Cayuga Lake (New York State, U.S.A.) and were used to evaluate the relative contributions of $\mathrm{Fe}, \mathrm{Mn}$ and $\mathrm{Al}$ oxides and organic material to total observed $\mathrm{Pb}$ and $\mathrm{Cd}$ adsorption by the surface coating materials. Several alternative selective extraction techniques were evaluated with respect to both selectivity and alteration of the residual unextracted material. $\mathrm{Pb}$ and $\mathrm{Cd}$ adsorption was measured under controlled laboratory conditions (mineral salts solution with defined metal speciation, ionic strength $0.05 \mathrm{M}, 25^{\circ} \mathrm{C}$ and $\mathrm{pH}$ 6.0) before and after extractions to determine by difference the adsorptive properties of the extracted component(s). Hydroxylamine hydrochloride $\left(0.01 \mathrm{M} \mathrm{NH} \mathrm{NH}_{2} \mathrm{OH} \cdot \mathrm{HCl}+0.01 \mathrm{M} \mathrm{HNO}_{3}\right)$ was used to selectively remove Mn oxides, sodium dithionite $\left(0.3 \mathrm{M} \mathrm{Na}_{2} \mathrm{~S}_{2} \mathrm{O}_{4}\right)$ was used to remove $\mathrm{Mn}$ and $\mathrm{Fe}$ oxides, and $10 \%$ oxalic acid was used to remove metal oxides and organic materials. Several other extractants were evaluated, but preliminary experiments indicated that they were not suitable for these experiments because of undesirable alterations of the residual, unextracted material. The selected extraction methods removed target components with efficiencies between 71 and $83 \%$, but significant amounts of metal oxides and organic materials other than the target components were also removed by the extractants (up to $39 \%$ ). Nonlinear regression analysis of the observed $\mathrm{Pb}$ and $\mathrm{Cd}$ adsorption based on the assumption of additive Langmuir adsorption isotherms was used to estimate the relative contributions of each surface coating constituent to total $\mathrm{Pb}$ and $\mathrm{Cd}$ binding of the biofilms. Adsorption of $\mathrm{Cd}$ to the lake biofilms was dominated by $\mathrm{Fe}$ oxides, with lesser roles attributed to adsorption by $\mathrm{Mn}$ and $\mathrm{Al}$ oxides and organic material. Adsorption of $\mathrm{Pb}$ was dominated by $\mathrm{Mn}$ oxides, with lesser roles indicated for adsorption to $\mathrm{Fe}$ oxides and organic material, and the estimated contribution of $\mathrm{Al}$ oxides to $\mathrm{Pb}$ adsorption was insignificant. The fitted $\mathrm{Pb}$ adsorption isotherm for $\mathrm{Fe}$ oxides was in excellent agreement with those obtained through direct experiments and reported in independent investigations. The estimated $\mathrm{Pb}$ distribution between surface coating components also agreed well with that previously predicted by an additive adsorption model based on $\mathrm{Pb}$ adsorption isotherms for laboratory surrogates for $\mathrm{Mn}, \mathrm{Fe}$ and $\mathrm{Al}$ oxides and defined biological components.
\end{abstract}

Key words - selective extraction, adsorption, lead, cadmium, iron oxide, manganese oxide

\section{INTRODUCTION}

The toxicity and bioaccumulation potential of heavy metals has prompted great interest in developing models to describe their transport and fate in aquatic environments. Development of meaningful models for trace metal phase distribution requires an understanding of trace metal adsorption onto solid phases and associated biofilms, which is a key factor influencing the residence time, bioavailability and effects of toxic metals on organisms in aquatic ecosystems (Krauskopf, 1956; Jenne, 1968; Turekian, 1977; Vuceta and Morgan, 1978; Murray, 1987; Santschi et al., 1997). In addition to the well established effects of solution chemistry (e.g. pH, ionic strength, metal speciation), trace metal adsorption is expected to be governed by the com- 
position of the solid phase, particularly the content of metal oxides and organic materials. Studies have been undertaken to quantify the relative roles of these components in controlling the adsorption of transition metals to surfaces in natural lake waters (Sigg, 1985), lake sediments (Tessier and Campbell, 1987) and biofilms (Nelson et al., 1995). However, there remains some uncertainty about the roles of metal oxides vs organic materials in controlling the adsorption of trace metals to natural heterogeneous materials. Indeed, some researchers report that metal oxides are the single most important determinant of trace metal adsorption (Krauskopf, 1956; Jenne, 1968), while others report that organic materials exert a stronger effect (Balistrieri and Murray, 1983; Salim, 1983; Sigg, 1985). Additionally, interactions between constituents could alter the metal adsorption properties of these constituents in a heterogeneous matrix (Davis and Leckie, 1978; Balistrieri and Murray, 1982; Tipping and Cooke, 1982; Honeyman and Santschi, 1988). The purpose of the research presented here is to use a new selective extraction approach to carefully elucidate the relative roles of metal oxides and organic materials. The resulting information is expected to facilitate the development of trace metal adsorption and transport models.

The use of selective extractants is a useful approach for determining the relative significance of the mineral and organic components in controlling trace metal adsorption. Extractants have previously been used to dissolve metal oxide or organic components in sediments and soils along with the trace metals associated with these components (Lindsay and Norvell, 1978; Tessier et al., 1979; Lion et al., 1982; Bauer and Kheboian, 1986; Martin et al., 1987; Tessier and Campbell, 1987; Luoma, 1989; Campbell and Tessier, 1991; Young et al., 1992; Young and Harvey, 1992). While useful for estimating trace metal bioavailability, selective extraction methods are difficult to use for accurately quantifying trace metals associated with specific biogeochemical phases because the extracted phases are operationally defined and are subject to experimental limitations such as removal of additional materials besides the target component during extraction. For example, when hydroxylamine hydrochloride $\left(\mathrm{NH}_{2} \mathrm{OH} \cdot \mathrm{HCL}+\mathrm{HNO}_{3}\right)$ is used to extract $\mathrm{Mn}$ oxides, the extraction reagent is likely to also extract some fraction of other components, such as other metal oxides and organic materials. Another limitation is that extractants can potentially desorb trace metals from other components that were not extracted, which would lead to an overestimation of trace metal associated with the target component. For example, when $\mathrm{NH}_{2} \mathrm{OH} \cdot \mathrm{HCL}+\mathrm{HNO}_{3}$ is used to extract $\mathrm{Mn}$ oxides and associated trace metals, the extraction reagent may also desorb trace metals from other surface components, such as Fe oxides. Yet another possi- bility is that metals extracted from one solid phase may readsorb to unextracted materials, which would lead to an underestimation of the importance of the extracted component.

In the present work, trace metal adsorption was measured for residues before and after selective extraction to avoid problems associated with desorption and/or readsorption of metals from other components. By determining metal adsorption isotherms for composite surface coatings before and after extraction, the adsorptive role of the removed component(s) was revealed by difference. The selectivities of the extractants were determined by measuring $\mathrm{Fe}, \mathrm{Mn}$ and $\mathrm{Al}$ concentrations and chemical oxygen demand (COD) before and after each extraction. Since standard extractants were found to remove significant quantities of non-target components, non-linear regression analysis of the adsorption isotherm data was used to determine the adsorptive contribution of each surface phase. This approach does not identify phase associations of contaminant metals already present on natural materials collected from the field because it relies on measuring adsorption of trace metals from defined solutions before and after extraction. Instead, this method provides an alternative means for estimating the reactive roles of metal oxide and organic phases in controlling trace metal adsorption in freshwater environments. In this way, this work contributes to the mechanistic understanding of trace metal associations with adsorptive components of the heterogeneous surfaces in natural aquatic environments.

For the experiments described here, natural biofilms that developed on glass slides in oxic lake waters were used to represent typical lake surface coating materials. It is expected that these surface coatings may also be representative of the materials contained in suspended particulate material (SPM) given their morphological and compositional similarities. Indeed, the biofilms in this study were likely formed in part by the deposition of SPM onto the glass slides. $\mathrm{Pb}$ and $\mathrm{Cd}$ adsorption to the collected biofilms was measured before and after selective extractions under conditions of controlled temperature, $\mathrm{pH}$ and solution chemistry. Extraction efficiency and selectivity were evaluated by analyzing for $\mathrm{Fe}, \mathrm{Mn}, \mathrm{Al}$ and $\mathrm{COD}$ concentrations before and after extractions with conventional extractants. In addition, several modifications of conventional extractants were tested as well as a novel extractant based on the use of $\mathrm{Ti}$ (III) as a reductant. $\mathrm{Pb}$ and $\mathrm{Cd}$ adsorption to each surface component was estimated through a non-linear regression analysis, and the results for $\mathrm{Pb}$ were compared to independent predictions based on representative laboratory surrogate materials for the oxide and organic phases. 


\section{MATERIALS AND METHODS}

\section{Development and characterization of natural biofilms}

Cayuga Lake in central New York State (U.S.A.) was chosen as the field site for collection of biofilms because of prior biofilm characterization by the researchers at this site (Nelson, 1997; Nelson et al., 1999b). Biofilms developed on glass microscope slides $(5.1 \times 7.6 \mathrm{~cm})$ held in polypropylene racks (Fluoroware, Chaska, MN, U.S.A.) that were submerged in the lake at a depth of approximately $30 \mathrm{~cm}$ for a period of 4 weeks. Several sets of biofilms were collected between January and March 1998, while the lake water temperature was approximately $4^{\circ} \mathrm{C}$. A similar collection method was reported by Tessier for collection of sediments on Teflon ${ }^{\circledR}$ sheets (Tessier et al. 1996). Prior to placement in the lake, glass slides and racks were precleaned with detergent, soaked for $24 \mathrm{~h}$ in soap solution, acid washed for $24 \mathrm{~h}$ in $6: 1(\mathrm{v} / \mathrm{v}) \mathrm{H}_{2} \mathrm{O}$ $\mathrm{HNO}_{3}$ (trace metal grade, Fisher Scientific, Pittsburgh, $\mathrm{PA})$, and then rinsed in distilled-deionized water $\left(\mathrm{dd}_{2} \mathrm{O}\right)$, followed by a second $24-\mathrm{h}$ acid wash and a final rinse in dd $\mathrm{H}_{2} \mathrm{O}$.

After retrieval from the lake, glass slides with attached biofilms were transported within $1 \mathrm{~h}$ to the laboratory (submerged in lake water) for microscopic examination, chemical characterization and measurement of $\mathrm{Pb}$ and $\mathrm{Cd}$ binding. Biofilms were consistent from slide to slide (Fe, $\mathrm{Mn}$ and $\mathrm{Al}$ concentrations varied by less than $5 \%$ ), allowing the use of different slides for characterizations and for measurement of $\mathrm{Pb}$ and $\mathrm{Cd}$ binding.

Organic material in the biofilms was quantified by measuring chemical oxygen demand (COD) using a modification of Standard Method \# 5220 B (APHA, 1995). The $\mathrm{COD}$, reported here in units of $\mathrm{mg} \mathrm{O}_{2} / \mathrm{L}$, is approximately equivalent to 2.7 times the organic carbon content in $\mathrm{mg}$ $\mathrm{C} / \mathrm{L}$ (assuming an oxidation state of zero for all organic carbon in the biofilm and $100 \%$ efficiency of oxidation to $\mathrm{CO}_{2}$ ). For the COD analysis, the slides with attached biofilms were broken into small pieces and placed in $250-\mathrm{mL}$ Erlenmeyer flasks. To each flask was added $50 \mathrm{~mL}$ $\mathrm{ddH}_{2} \mathrm{O}, 0.3 \mathrm{~g} \mathrm{HgSO}_{4}, 5 \mathrm{~mL}$ sulfuric acid reagent (w/ $\mathrm{Ag}_{2} \mathrm{SO}_{4}$ ), $25 \mathrm{~mL}$ of $0.00417 \mathrm{M} \mathrm{K}_{2} \mathrm{Cr}_{2} \mathrm{O}_{7}$ and an additional $70 \mathrm{~mL}$ of sulfuric acid reagent. These solutions were refluxed for $2 \mathrm{~h}$, cooled and the remaining $\mathrm{Cr}_{2} \mathrm{O}_{7}^{2-}$ was titrated with standardized $0.025 \mathrm{M}$ ferrous ammonium sulfate.

Total extractable metal concentrations ( $\mathrm{Fe}, \mathrm{Mn}, \mathrm{Al})$ in the biofilms were determined by extracting with $50 \mathrm{~mL}$ of $10 \% \quad \mathrm{HNO}_{3}$ (trace metal grade, Fisher Scientific, Pittsburgh, PA, U.S.A.) for 24 h. Acid extracts were analyzed by graphite furnace atomic absorption spectrometry (GFAAS) using a Perkin Elmer (Norwalk, CT, U.S.A.) AAnalyst 100 equipped with a HGA 800 graphite furnace and an AS-72 autosampler.

\section{Selective extraction techniques}

Each biofilm-coated slide was extracted in $50 \mathrm{~mL}$ of extraction reagent in $150 \mathrm{~mm}$ plastic petri dishes using several extraction techniques. Our initial experiments with a previously reported hydroxylamine extraction method for selective removal of $\mathrm{Mn}$ and $\mathrm{Fe}$ oxides $(0.04 \mathrm{M}$ $\mathrm{NH}_{2} \mathrm{OH} \cdot \mathrm{HCl}, 25 \%$ acetic acid, $6 \mathrm{~h}$ at $95^{\circ} \mathrm{C}$ ) (Tessier et al., 1979; Young et al., 1992; Young and Harvey, 1992) suggested that the high temperature altered adsorption characteristics of the remaining organic material. There was also evidence that the acetic acid increased the organic content (COD) of the extracted biofilms. The added COD was likely the result of acetate binding to the biofilm and could be expected to alter trace metal adsorption. Thus, we modified this extraction procedure by reducing the temperature to $25^{\circ} \mathrm{C}$, reducing the $\mathrm{NH}_{2} \mathrm{OH} \cdot \mathrm{HCl}$ concentration to $0.01 \mathrm{M}$, eliminating the acetic acid and reducing the extraction time to $30 \mathrm{~min}$.
Preliminary experiments with a previously reported sodium dithionite reagent to extract $\mathrm{Fe}$ oxides $[0.3 \mathrm{M}$ $\mathrm{Na}_{2} \mathrm{~S}_{2} \mathrm{O}_{4}$ with a citrate buffer $(0.175 \mathrm{M}$ Na-citrate +0.025 citric acid)] (Anderson and Jenne, 1970; Tessier et al., 1979 ) indicated that this reagent caused the organic content of the biofilms to increase by a factor of two as measured by COD. Similar to the difficulty with acetic acid extraction noted above, this increase was presumably caused by citrate binding to the biofilm which would interfere with accurate subsequent measurement of $\mathrm{Pb}$ and $\mathrm{Cd}$ adsorption. Thus, we eliminated the citrate buffer from the reagent, and $\mathrm{pH}$ was controlled at 6.0 by manual addition of dilute $\mathrm{HNO}_{3}$ or $\mathrm{NaOH}$ solutions. The final modified extraction procedure used $50 \mathrm{~mL}$ of $0.3 \mathrm{M} \mathrm{Na} \mathrm{S}_{2} \mathrm{O}_{4}$ for $40 \mathrm{~min}$ at $\mathrm{pH}$ 6.0. This extractant was prepared just before use to avoid any reduction of $\mathrm{S}_{2} \mathrm{O}_{4}^{2-}$.

Extraction with $10 \%$ oxalic acid for $60 \mathrm{~h}$ (Ramsay et al., 1988) was employed to remove organic materials from biofilms, but also removed most of the metal oxides (see the Results Section).

Several extraction reagents based on $\mathrm{Ti}(\mathrm{III})$ as a reductant were evaluated for use in selectively removing $\mathrm{Fe}$ oxides. Hudson and Morel (1989) employed a Ti(III) reagent containing $0.05 \mathrm{M} \mathrm{Ti}, 0.05 \mathrm{M}$ EDTA and $0.05 \mathrm{M}$ citrate, and the extraction was carried out for $15 \mathrm{~min}$ at room temperature. The Ti(III) solutions used in this procedure are unstable without EDTA and citrate buffer. Since residual EDTA or citrate could influence $\mathrm{Pb}$ and $\mathrm{Cd}$ adsorption, the use of this reagent was discontinued in subsequent experiments.

\section{A. $\mathrm{Pb}$ adsorption in the presence and absence of $\mathrm{Cd}$.}

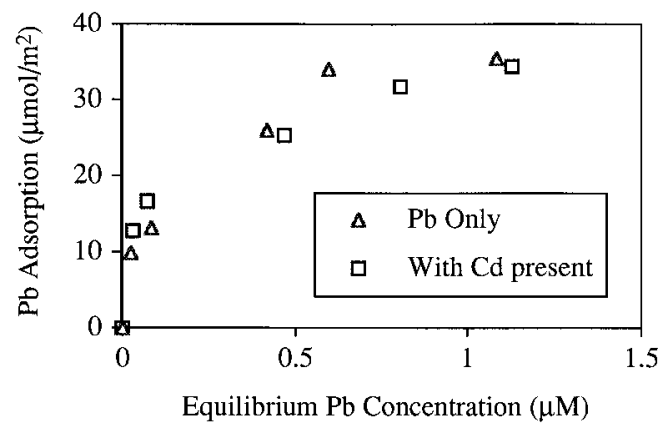

\section{B. Cd adsorption in the presence and absence of $\mathrm{Pb}$}

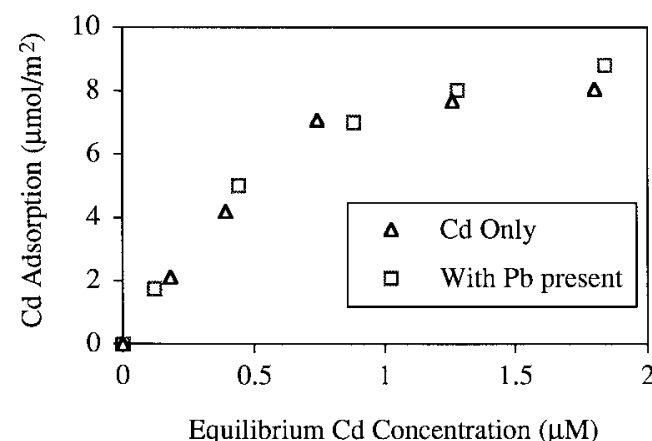

Fig. 1. Test for adsorption interference between $\mathrm{Cd}$ and $\mathrm{Pb}$. A. $\mathrm{Pb}$ adsorption to biofilms in the presence and absence of $\mathrm{Cd}$. B. Cd adsorption in the presence and absence of $\mathrm{Pb}$. For adsorption from mixtures, the initial levels $(\mu \mathrm{M})$ of $\mathrm{Cd}$ and $\mathrm{Pb}$ were equal. 
Table 1. Composition and $\mathrm{Pb} / \mathrm{Cd}$ speciation of MMS solution used in metal adsorption experiments

\begin{tabular}{|c|c|c|c|}
\hline & Component or species & Concentration $(\mu \mathrm{M})$ & Concentration $(\mathrm{mg} / \mathrm{l})$ \\
\hline MMS medium ${ }^{\mathrm{a}}$ & $\begin{array}{c}\mathrm{CaCl}_{2} \cdot 2 \mathrm{H}_{2} \mathrm{O} \\
\mathrm{MgSO}_{4} \cdot 7 \mathrm{H}_{2} \mathrm{O} \\
\left(\mathrm{NH}_{4}\right)_{2} \mathrm{SO}_{4} \\
\mathrm{KNO}_{3} \\
\mathrm{NaHCO}_{3} \\
\mathrm{KH}_{2} \mathrm{PO}_{4}\end{array}$ & $\begin{array}{r}200 \\
140 \\
910 \\
150 \\
10 \\
5\end{array}$ & $\begin{array}{r}30 \\
35 \\
120 \\
15 \\
0.84 \\
0.70\end{array}$ \\
\hline $\mathrm{Pb}$ speciation $^{\mathrm{b}}$ & $\begin{array}{c}\mathrm{Pb}^{2+} \\
\mathrm{PbSO}_{4} \\
\mathrm{PbOH}^{+}\end{array}$ & $\begin{array}{r}89 \% \\
9 \% \\
1 \%\end{array}$ & \\
\hline $\mathrm{Cd}_{\text {speciation }^{\mathrm{b}}}$ & $\begin{array}{c}\mathrm{Cd}^{2+} \\
\mathrm{Cd} \mathrm{Cl}^{+} \\
\mathrm{Cd} \mathrm{SO}_{4} \\
\mathrm{Cd} \mathrm{NO}_{3}^{+}\end{array}$ & $\begin{array}{r}89 \% \\
1.5 \% \\
4.6 \% \\
4.9 \%\end{array}$ & \\
\hline
\end{tabular}

${ }^{\mathrm{a}}$ Ionic strength adjusted to $0.05 \mathrm{M} \mathrm{w} / \mathrm{NaNO}_{3}$; $\mathrm{pH}$ adjusted to 6.0 before autoclaving.

${ }^{\mathrm{b}} \mathrm{Pb}$ and $\mathrm{Cd}$ speciation calculated by MINEQL for a total $\mathrm{Pb} / \mathrm{Cd}$ concentration of $1.0 \mu \mathrm{M}$.

\section{Measurement of $\mathrm{Pb}$ and $\mathrm{Cd}$ adsorption to natural biofilms}

$\mathrm{Pb}$ and $\mathrm{Cd}$ adsorption isotherms were obtained for extracted and unextracted biofilms by measuring $\mathrm{Pb}$ and $\mathrm{Cd}$ adsorption from solutions with defined metal speciation and initial $\mathrm{Pb}$ and $\mathrm{Cd}$ concentrations ranging from 0.2 to $2.0 \mu \mathrm{M}$. The equilibration solutions were prepared by dilution of $1000 \mathrm{mg} / \mathrm{L} \mathrm{PbNO}_{3}$ and $\mathrm{CdNO}_{3}$ reference solutions (Fisher Scientific, Pittsburgh, PA, U.S.A.) using a minimal mineral salts (MMS) solution with ionic strength adjusted to $0.05 \mathrm{M}$ with $\mathrm{NaNO}_{3}$ (Table 1). $\mathrm{Pb}$ and $\mathrm{Cd}$ speciation in the defined solutions was calculated using MINEQL (Westall et al., 1976). The calculations showed that because of low inorganic ligand concentrations, free $\mathrm{Pb}^{2+}$ or $\mathrm{Cd}^{2+}$ ions would comprise $89 \%$ of the total dissolved metal (Table 1). Three slides from each treatment were placed in polypropylene racks and submerged into each of five $800-\mathrm{mL}$ solutions with five different $\mathrm{Pb}$ and $\mathrm{Cd}$ concentrations. These solutions were contained in 2-L water-jacketed beakers to maintain a constant temperature of $25 \pm 1^{\circ} \mathrm{C}$. The solutions were stirred continuously with magnetic stirrers for $24 \mathrm{~h}$ while maintaining the $\mathrm{pH}$ at $6.0 \pm 0.1$ using $\mathrm{pH}$ controllers (Cole Parmer, Vernon Hills, IL) to regulate the addition of $0.01 \mathrm{M} \mathrm{HNO}_{3}$ and $\mathrm{NaOH}$. After equilibration, slides with biofilms were removed from the $\mathrm{Pb}$ and $\mathrm{Cd}$ solutions, rinsed for $1 \mathrm{~s}$ in metal-free MMS solution, and extracted into $50 \mathrm{~mL}$ of $10 \% \mathrm{HNO}_{3}$ (trace metal grade) for $24 \mathrm{~h}$ in $150 \mathrm{~mm}$ plastic petri dishes. $\mathrm{Pb}$ and $\mathrm{Cd}$ in extracts were measured using GFAAS as described above. The coefficient of variation for the GFAAS analyses was less than $5 \%$.

Preliminary experiments with $\mathrm{Pb}$ and $\mathrm{Cd}$ adsorption measured together and separately showed that $\mathrm{Cd}$ did not interfere with $\mathrm{Pb}$ adsorption to the biofilms and vice versa under the conditions of these experiments (Fig. 1). This permitted the simultaneous measurement of $\mathrm{Pb}$ and $\mathrm{Cd}$ adsorption in subsequent experiments.

\section{Statistical analyses}

As described above, none of the selective extractions removed only one component from the biofilms without also partially removing at least one of the other components as well. Accurate determination of $\mathrm{Pb}$ and $\mathrm{Cd}$ associated with each individual component (by difference before and after extraction) thus required consideration of contributions from the partial fractions of the other components removed from the slides. Tessier et al. (Tessier et al., 1996) recently addressed this problem by using simultaneous solution of two equations for $\mathrm{Fe}$ and $\mathrm{Mn}$ contributions to trace metal binding. Because our work included additional variables (i.e. $\mathrm{Fe}$ and $\mathrm{Mn}$, as well as $\mathrm{Al}$ oxides and organic materials) $\mathrm{Pb}$ and $\mathrm{Cd}$ adsorption to each component was estimated with non-linear regression analyses of all of the isotherm data including unaltered biofilms and biofilms after each of the three extractions. The model used for the regression analysis considered total adsorption by the biofilm at a given $\mathrm{Pb}$ or $\mathrm{Cd}$ concentration ( $\Gamma_{\text {total }}, \mu \mathrm{mol} \mathrm{Pb}$ or $\mathrm{Cd} / \mathrm{m}^{2}$ ) to be the sum of contributions from four constituents (Fe, Mn and $\mathrm{Al}$ oxides and $\mathrm{COD}$ ):

$$
\begin{aligned}
\Gamma_{\text {total }}= & C_{\mathrm{Fe}} \cdot \Gamma_{\mathrm{Fe}}+C_{\mathrm{Mn}} \cdot \Gamma_{\mathrm{Mn}}+C_{\mathrm{Al}} \cdot \Gamma_{\mathrm{Al}}+C_{\mathrm{COD}} \\
& \cdot \Gamma_{\mathrm{COD}},
\end{aligned}
$$

where $C_{\mathrm{Fe}}, C_{\mathrm{Mn}}, C_{\mathrm{Al}}$ and $C_{\mathrm{COD}}$ are the surface concentrations of each component ( $\mu \mathrm{mol} \mathrm{Fe}, \mathrm{Mn}$ or $\mathrm{Al} / \mathrm{m}^{2}$ and $\left.\mathrm{mg} \operatorname{COD} / \mathrm{m}^{2}\right)$ and the $\Gamma$ terms are adsorption on a per quantity of material basis (e.g. $\mu \mathrm{mol} \mathrm{Pb} / \mu \mathrm{mol} \mathrm{Fe}$ ). $\Gamma$ for each component was expressed as a Langmuir adsorption isotherm:

$$
\Gamma_{i}=\frac{\Gamma_{i}^{\max } K_{i}\left[\mathrm{M}^{2+}\right]}{1+K_{i}\left[\mathrm{M}^{2+}\right]},
$$

where $\Gamma_{i}$ is the adsorption of $\mathrm{M}^{2+}$ by component $i$ per unit surface area, $\Gamma_{i}^{\max }$ is the maximum adsorption of $\mathrm{M}^{2+}$ by component $i, K_{i}$ is the Langmuir equilibrium coefficient and $\left[\mathrm{M}^{2+}\right]$ is the concentration of free $\mathrm{Pb}$ or $\mathrm{Cd}$ metal ions. The predicted metal adsorption to bare glass slides at each metal concentration was subtracted from the observed metal adsorption. Adsorption to each component is expressed per unit nominal surface area of the glass slides containing the biofilm, not the total surface area of the adsorbing phase.

The nonlinear regression was performed using SAS software (SAS Version 6.12, SAS Institute, Cary, NC). The regression minimized the error associated with a total of eight variables (four values of $\Gamma_{i}^{\max }$ and four values of $K_{i}$ ). The data set consisted of adsorption data for the unextracted biofilms plus biofilms extracted with each of the three extractants, with triplicate samples at five metal concentrations, for a total of 60 observations. The regression was initialized with estimates for each $\Gamma_{i}^{\max }$ based on the assumption that all components adsorbed equal surface concentrations of metal. If the algorithm did not initially converge when all eight variables were regressed, the regression was performed iteratively for the four values of $\Gamma_{i}^{\max }$ and the four values of $K_{i}$ until convergence on both $\Gamma_{i}^{\max }$ and $K_{i}$ was obtained. 
Table 2. . Assessment of removal of organic material and metal oxides from natural coatings by selective extractions

\begin{tabular}{|c|c|c|c|c|c|c|c|c|}
\hline \multirow[t]{2}{*}{ Extractant } & \multicolumn{2}{|c|}{ Organic material $^{\mathrm{a}}$} & \multicolumn{2}{|l|}{$\mathrm{Fe}$ oxide $^{\mathrm{b}}$} & \multicolumn{2}{|l|}{ Mn oxide ${ }^{b}$} & \multicolumn{2}{|l|}{ Al oxide ${ }^{b}$} \\
\hline & $\begin{array}{l}\text { Surf. Conc. } \\
\left(\mathrm{mg} \text { COD } / \mathrm{m}^{2}\right)\end{array}$ & $\begin{array}{c}\text { Removal } \\
(\%)\end{array}$ & $\begin{array}{l}1 \text { Surf. Conc. } \\
\left(\mu \mathrm{mol} \mathrm{Fe} / \mathrm{m}^{2}\right)\end{array}$ & $\begin{array}{c}\text { Removal } \\
(\%)\end{array}$ & $\begin{array}{l}\text { Surf. Conc. } \\
\left(\mu \mathrm{mol} \mathrm{Mn} / \mathrm{m}^{2}\right)\end{array}$ & $\begin{array}{c}\text { Removal } \\
(\%)\end{array}$ & $\begin{array}{l}1 \text { Surf. Conc. } \\
\left(\mu \mathrm{mol} \mathrm{Al} / \mathrm{m}^{2}\right)\end{array}$ & $\begin{array}{c}\text { Removal } \\
(\%)\end{array}$ \\
\hline None (total acid extractable) & $484 \pm 29$ & 0 & $353 \pm 19$ & 0 & $21.5 \pm 0.3$ & 0 & $767 \pm 26$ & 0 \\
\hline $0.01 \mathrm{M} \mathrm{NH} \mathrm{N}_{2} \mathrm{OH} \cdot \mathrm{HCl}+0.01 \mathrm{M} \mathrm{HNO}_{3} 30 \mathrm{~min}$ & $330 \pm 54$ & 32 & $302 \pm 25$ & 14 & $6.3 \pm 0.7$ & 71 & $470 \pm 54$ & 39 \\
\hline $0.3 \mathrm{M} \mathrm{Na}_{2} \mathrm{~S}_{2} \mathrm{O}_{4} 40 \mathrm{~min}$ & $470 \pm 25$ & 3 & $60.2 \pm 1.4$ & 83 & $1.7 \pm 0.14$ & 92 & $134 \pm 7.2$ & 83 \\
\hline $10 \%$ Oxalic Acid $60 \mathrm{~h}$ & $88 \pm 3$ & 82 & $15.4 \pm 2.5$ & 96 & $<0 . \overline{6}\left(\mathrm{bd}^{3}\right)$ & 100 & $29.6 \pm 4.8$ & 96 \\
\hline
\end{tabular}

${ }^{\text {a Mean }}(n=3) \pm$ one standard deviation.

${ }^{\mathrm{b}}$ Mean $(n=15) \pm$ one standard deviation.

Determination of adsorption isotherms for laboratory surrogate materials

For comparison to results of the selective extraction experiments, $\mathrm{Pb}$ adsorption isotherms were determined for pure laboratory surrogate materials representing the $\mathrm{Fe}$, $\mathrm{Mn}$ and $\mathrm{Al}$ oxides and organic materials in the natural biofilms. Fe oxyhydroxide was prepared by precipitation of $\mathrm{Fe}(\mathrm{III})$ by addition of $\mathrm{NaOH}$ to a $0.1 \mathrm{M} \mathrm{Fe}\left(\mathrm{NO}_{3}\right)_{3}$ solution to reach a $\mathrm{pH}$ of 8.0 (Matijevic and Scheiner, 1978). The resulting colloidal suspension exhibited an X-ray diffraction pattern that suggested an amorphous structure. Biogenic Mn oxides were prepared via biologically catalyzed oxidation of $\mathrm{Mn}(\mathrm{II})$ by the bacterium Leptothrix discophora SS-1 (Nelson et al., 1999a). A fresh abiotic $\mathrm{Mn}(\mathrm{IV})$ oxide was prepared by oxidation of Mn(II) with $\mathrm{KMNO}_{4}$ and $\mathrm{NaOH}$ at $90^{\circ} \mathrm{C}$ (Murray, 1974). Al oxide

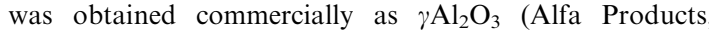
Danvers, MS, U.S.A.) (Nelson et al., 1999b). Pb adsorption to the laboratory oxides was determined by equilibrating suspensions of the oxides with $\mathrm{Pb}$ solutions prepared in MMS and maintained at $\mathrm{pH} 6.0$ and $25^{\circ} \mathrm{C}$ for $24 \mathrm{~h}$. $\mathrm{Pb}$ adsorption was determined by measuring $\mathrm{Pb}$ concentrations (GFAAS) before and after centrifuging at $12,900 \mathrm{rpm}$ for $30 \mathrm{~min}$.

Surrogates for the biological components of the natural biofilms were laboratory biofilms of pure cultures of the bacteria Burkholdaria cepacia strain 17616 and L. discophora strain SS-1. Biofilms were grown on glass slides in a biofilm reactor (Nelson et al., 1996) and $\mathrm{Pb}$ adsorption was measured using the same method as that described above for the lake biofilms.

\section{RESULTS AND DISCUSSION}

Biofilms that developed on glass slides after four weeks in Cayuga Lake consisted of assemblages of microorganisms in a biofilm matrix and associated mineral deposits. The biofilms contained large numbers of diatoms, green and red algae, bacterial cells, filamentous cyanobacteria and filamentous bacteria resembling iron-depositing bacteria such as Leptothrix spp. (Ghiorse, 1984). The biological composition of Cayuga Lake biofilms is described more extensively elsewhere (Nelson, 1997; Nelson et al., 1999b). Microscopic observation after staining with Prussian Blue and Leukoberbelin Blue revealed strong associations between $\mathrm{Fe}$ and $\mathrm{Mn}$ mineral deposits and organic materials. From the present investigation it was not possible to determine if the $\mathrm{Fe}$ and $\mathrm{Mn}$ oxides were formed by oxidation in the biofilm or if these oxides were formed in the water column and then deposited onto the biofilm sur- faces. The total organic material in the biofilms exerted a chemical oxygen demand (COD) of $484 \pm 29 \mathrm{mg} / \mathrm{m}^{2}$ (Table 2). Surface concentrations of metal oxides decreased in the order $\mathrm{Al}>\mathrm{Fe}>\mathrm{Mn}$ (Table 2).

The extractant reagents employed were intended to selectively remove specific adsorbing phases without removing other components. Hydroxylamine hydrochloride $\left(\mathrm{NH}_{2} \mathrm{OH} \cdot \mathrm{HCl}\right)$ was used to extract easily reducible $\mathrm{Mn}$ oxides, sodium dithionite $\left(\mathrm{Na}_{2} \mathrm{~S}_{2} \mathrm{O}_{4}\right)$ to extract $\mathrm{Mn}$ and $\mathrm{Fe}$ oxides, and oxalic acid to extract metal oxides and organic material. As noted in the Methods Section above, use of other extractants resulted in unacceptable alterations of the residual biofilms. Each extractant removed additional components besides the target materials. $\mathrm{NH}_{2} \mathrm{OH} \cdot \mathrm{HCl}$ removed $71 \%$ of the biofilm $\mathrm{Mn}$, but also removed $14 \%$ of the $\mathrm{Fe}, 39 \%$ of the $\mathrm{Al}$ and $32 \%$ of the organic material (Table 2). $\mathrm{Na}_{2} \mathrm{~S}_{2} \mathrm{O}_{4}$ removed 83 and $92 \%$ of the Fe and $\mathrm{Mn}$, respectively, but also removed $83 \%$ of the Al. Very little $(3 \%)$ of the organic material was removed by the $\mathrm{Na}_{2} \mathrm{~S}_{2} \mathrm{O}_{4}$ extractant. Oxalic acid removed $82 \%$ of the organic material, but also removed nearly all of the Fe, Mn and $\mathrm{Al}$ (Table 2).

$\mathrm{Pb}$ and $\mathrm{Cd}$ adsorption to the unextracted biofilms at $\mathrm{pH} 6.0$ and $25^{\circ} \mathrm{C}$ followed Langmuir adsorption isotherms, and $\mathrm{Pb}$ adsorption was almost an order of magnitude greater than that of $\mathrm{Cd}$ (Figs 2 and 3). Extraction with $\mathrm{NH}_{2} \mathrm{OH} \cdot \mathrm{HCl}$ and $\mathrm{Na}_{2} \mathrm{~S}_{2} \mathrm{O}_{4}$ significantly reduced both $\mathrm{Pb}$ and $\mathrm{Cd}$ adsorption, and adsorption to biofilms extracted with oxalic acid was only slightly greater than that of bare glass (Figs 2 and 3).

Relative contributions of metal oxide and organic phases to total observed $\mathrm{Pb}$ and $\mathrm{Cd}$ adsorption by the biofilms were estimated using nonlinear regression analysis of biofilm composition data and adsorption data for extracted and unextracted biofilms. This analysis provided estimates of Langmuir parameters $\left(\Gamma_{\max }\right.$ and $\left.K\right)$ for each of the components for both $\mathrm{Pb}$ and $\mathrm{Cd}$ adsorption (Table 3). These parameters were then used to construct adsorption isotherms for the original unextracted biofilms showing estimated adsorption to each of the components considered in the model. For $\mathrm{Pb}$, 

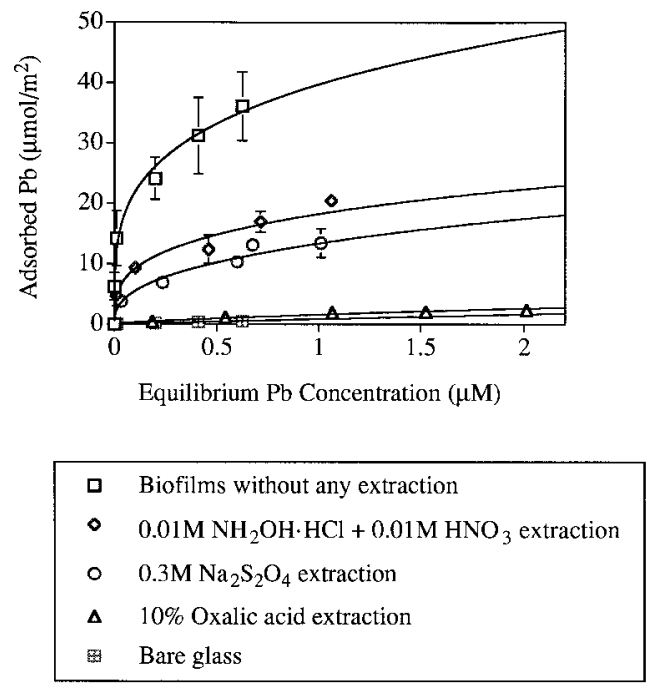

Fig. 2. $\mathrm{Pb}$ adsorption to Cayuga Lake biofilms before and after several selective extraction treatments. Error bars indicate \pm one standard deviation.

the regression analysis indicates that the greatest contribution to total $\mathrm{Pb}$ adsorption was from $\mathrm{Mn}$ oxides, followed by lesser contributions from $\mathrm{Fe}$ oxides and organic material (Fig. 4). The estimated contribution to $\mathrm{Pb}$ adsorption by $\mathrm{Al}$ oxides was negligible (Table $3, \Gamma_{\mathrm{Al}}^{\max }=0.00 \pm 0.0035 \mathrm{~mol} \mathrm{~Pb} /$
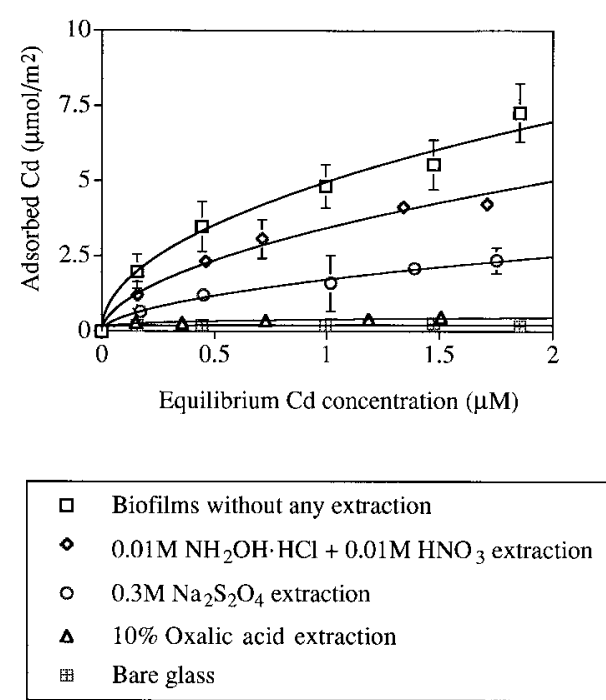

Fig. 3. Cd adsorption to Cayuga Lake biofilms before and after several selective extraction treatments. Error bars indicate \pm one standard deviation.

mol $\mathrm{Al}$ ). For $\mathrm{Cd}$, the regression analysis indicated that $\mathrm{Fe}$ oxides exerted the greatest influence on $\mathrm{Cd}$ binding, followed by lesser contributions from $\mathrm{Al}$ oxides, Mn oxides and organic material (Fig. 5). However, at low $\mathrm{Cd}$ concentrations $(<0.1 \mu \mathrm{M})$, the estimated contribution of $\mathrm{Mn}$ was much greater

Table 3. Estimated Langmuir parameters for $\mathrm{Pb}$ and $\mathrm{Cd}$ adsorption to organic material and metal oxides in Cayuga Lake biofilms based on a nonlinear regression analysis of adsorption after selective extractions

\begin{tabular}{|c|c|c|c|c|}
\hline \multirow[t]{2}{*}{ Parameter } & \multicolumn{2}{|c|}{ Lead } & \multicolumn{2}{|c|}{ Cadmium } \\
\hline & Estimate & Asymptotic Std. Error & Estimate & Asymptotic Std. Error \\
\hline$\Gamma_{\operatorname{maxFe}}(\mathrm{mol} / \mathrm{mol} \mathrm{Fe})$ & 0.0363 & 0.0092 & 0.0099 & 0.0017 \\
\hline$\Gamma_{\operatorname{maxMn}}(\mathrm{mol} / \mathrm{mol} \mathrm{Mn})$ & 0.833 & 0.054 & 0.0402 & 0.013 \\
\hline$\Gamma_{\operatorname{maxAl}}(\mathrm{mol} / \mathrm{mol} \mathrm{Al})$ & 0.000 & 0.0035 & 0.0076 & 0.0035 \\
\hline$\Gamma_{\operatorname{maxCOD}}(\mathrm{mol} / \mathrm{mg} \mathrm{COD})$ & 0.0245 & 0.0023 & 0.0052 & 0.00067 \\
\hline$K_{\mathrm{Fe}}(\mathrm{L} / \mu \mathrm{mol})$ & 1.97 & 0.59 & 1.75 & 0.53 \\
\hline $\mathrm{K}_{\mathrm{Mn}}(\mathrm{L} / \mu \mathrm{mol})$ & 319 & 81.4 & 22.3 & 48 \\
\hline $\mathrm{K}_{\mathrm{Al}}(\mathrm{L} / \mu \mathrm{mol})$ & - & - & 0.13 & 0.046 \\
\hline $\mathrm{K}_{\mathrm{COD}}(\mathrm{L} / \mu \mathrm{mol})$ & 3.8 & 0.97 & 0.65 & 0.15 \\
\hline
\end{tabular}
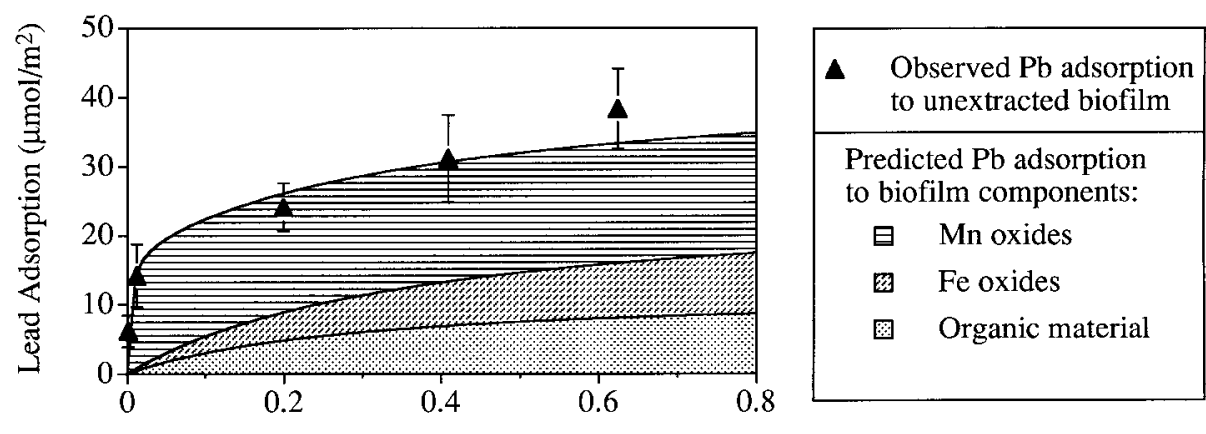

Equilibrium $\mathrm{Pb}$ Concentration $(\mu \mathrm{M})$

Fig. 4. Estimated $\mathrm{Pb}$ adsorption to metal oxide and organic components of unextracted Cayuga Lake biofilms based on non-linear regression analysis of $\mathrm{Pb}$ adsorption isotherm data for extracted and unextracted biofilms. Error bars indicate \pm one standard deviation. 


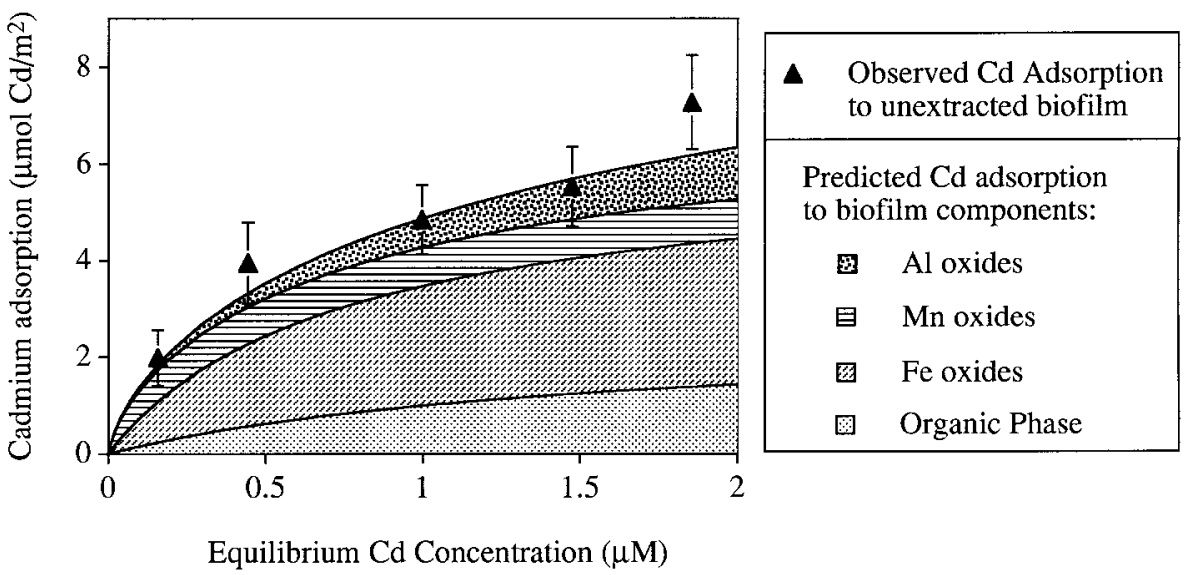

Fig. 5. Estimated Cd adsorption to metal oxide and organic components of unextracted Cayuga Lake biofilms based on non-linear regression analysis of $\mathrm{Cd}$ adsorption isotherm data for extracted and unextracted biofilms. Error bars indicate \pm one standard deviation.

than that of organic material and $\mathrm{Al}$ oxides and similar to that of Fe (Fig. 5). Errors associated with estimated adsorption to each phase are depicted in Fig. 6, which shows $\mathrm{Pb}$ and $\mathrm{Cd}$ adsorption at a single adsorbate concentration $(0.5 \mu \mathrm{M})$. The standard errors depicted in Fig. 6 were determined by considering the propagated errors from both $\Gamma_{\max }$ and $K$ estimations. These calculations indicate that the higher adsorption of $\mathrm{Pb}$ by $\mathrm{Mn}$ is statistically significant. The estimated $\mathrm{Pb}$ adsorption by $\mathrm{Fe}$ was not significantly different from that of organic material.

The distribution of $\mathrm{Pb}$ between biofilm components estimated by the non-linear regression analysis is similar to that estimated for Cayuga Lake biofilms using an adsorption additivity model (Nelson et al., 1999b). In the additivity model, total adsorption was predicted from the sum of contributions of individual components that were determined using $\mathrm{Pb}$ adsorption isotherms for pure laboratory surrogate materials selected to represent

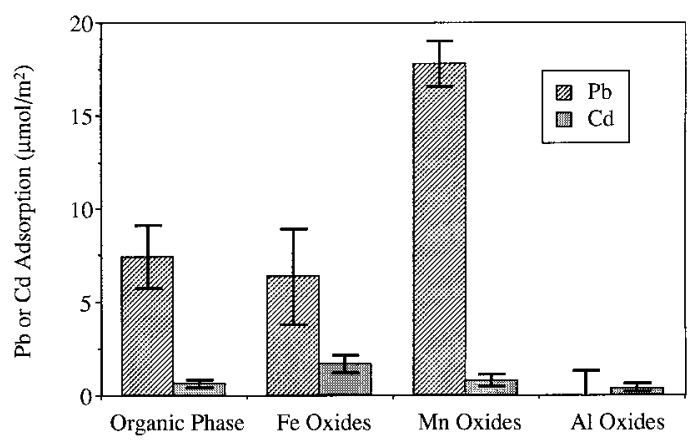

Fig. 6. Estimated $\mathrm{Pb}$ and $\mathrm{Cd}$ adsorption to metal oxide and organic components of Cayuga Lake biofilms for dissolved metal concentrations of $0.5 \mu \mathrm{M}$. Error bars indicate asymptotic standard error of the mean for the non-linear regression analysis. natural $\mathrm{Fe}, \mathrm{Mn}$, and $\mathrm{Al}$ oxides and organic material. When the adsorption capacity of laboratoryderived biogenic Mn oxides was used as the surrogate for natural Mn oxides (Nelson et al., 1999a), the additivity model predicted a strong role of $\mathrm{Mn}$ oxides (Nelson et al., 1999b) similar to that observed in the present work. The additivity model used $\mathrm{Pb}$ adsorption to pure cultures of microorganisms to estimate $\mathrm{Pb}$ adsorption to the organic phase of the biofilms, and resulted in a lower estimation of the role of organic material than in the present work. The low concentration of $\mathrm{Pb}$ associated with Al oxides predicted by the selective extractions also agrees with predictions based on laboratory adsorption isotherms. Based on previously measured $\mathrm{Pb}$ adsorption to $\gamma \mathrm{Al}_{2} \mathrm{O}_{3}$ (Nelson, 1997; Nelson et al., 1999b), the expected $\Gamma_{\max }$ for Al oxide in the unextracted Cayuga Lake biofilms would be $1.2 \mu \mathrm{mol}$ $\mathrm{Pb} / \mathrm{m}^{2}$, which is much lower than $\mathrm{Pb}$ adsorption measured for the other oxide and organic phases.

The regression analysis provides Langmuir adsorption isotherms for each of the biofilm components investigated, and these can be compared to $\mathrm{Pb}$ adsorption isotherms for representative laboratory materials determined under the same conditions (MMS solution matrix at $25^{\circ} \mathrm{C}, \mathrm{pH} 6.0$, ionic strength $0.05 \mathrm{M}$ ). The regression-derived $\mathrm{Pb}$ adsorption isotherm for the $\mathrm{Fe}$ oxide component of the biofilms was very similar to $\mathrm{Pb}$ adsorption to amorphous $\mathrm{Fe}$ oxyhydroxide previously measured in our lab (Nelson et al., 1995) as well as to that estimated using a model described by Benjamin and Leckie (1981) (Fig. 7). The excellent agreement of the $\mathrm{Pb}$ adsorptive behavior of $\mathrm{Fe}$ oxides obtained from these distinctly different approaches suggests that the isotherm parameters have a predictive utility. The agreement of the regression results for the $\mathrm{Pb}$ isotherm to those independently attained by other methods also suggests the extraction approach 


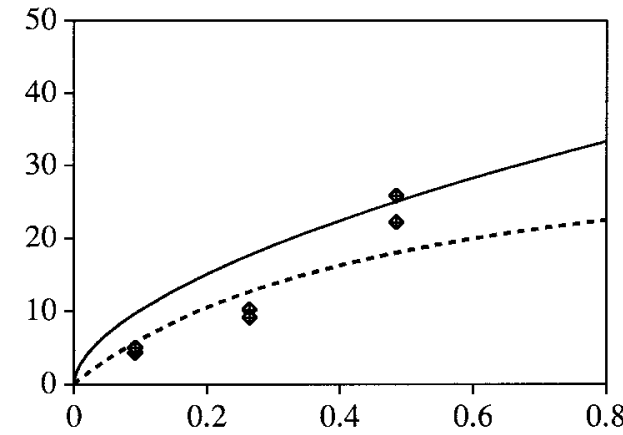

..... Pb Adsorption on Fe oxides in Cayuga Lake biofilms Predicted from Regression

- Measured Pb Adsorption to Fe Colloid Deposits

$\mathrm{Pb}$ Adsorption to Fe oxide predicted by the model of Benjamin and Leckie (1981)

Equilibrium $\mathrm{Pb}$ Concentration $(\mu \mathrm{M})$

Fig. 7. Comparison of $\mathrm{Pb}$ adsorption to $\mathrm{Fe}$ oxide predicted by the non-linear regression analysis of extracted biofilm data to that measured for Fe colloids and that reported by Benjamin and Leckie

(1981). Temperature $=25^{\circ} \mathrm{C}, \mathrm{pH}$ 6.0. Adsorption to Fe colloid data after Nelson et al. (1995).

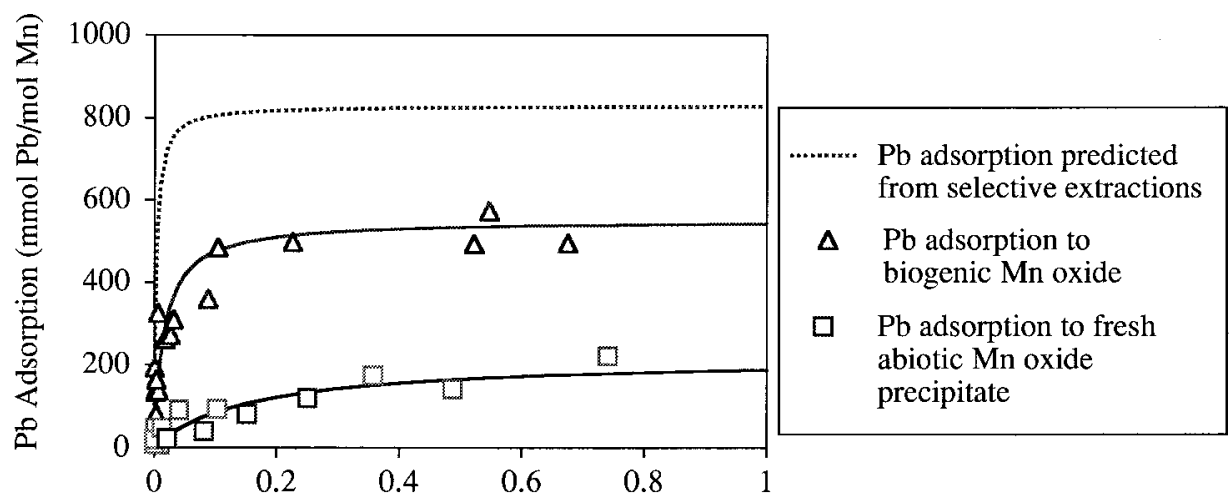

Equilibrium $\mathrm{Pb}$ Concentration $((\mu \mathrm{M})$

Fig. 8. Comparison of $\mathrm{Pb}$ adsorption to $\mathrm{Mn}$ oxide predicted by the non-linear regression analysis of extracted biofilm data to that measured for biogenic $\mathrm{Mn}$ oxide and a fresh abiotically precipitated Mn oxide. Data for adsorption to biogenic Mn oxide after Nelson et al. (1999a).

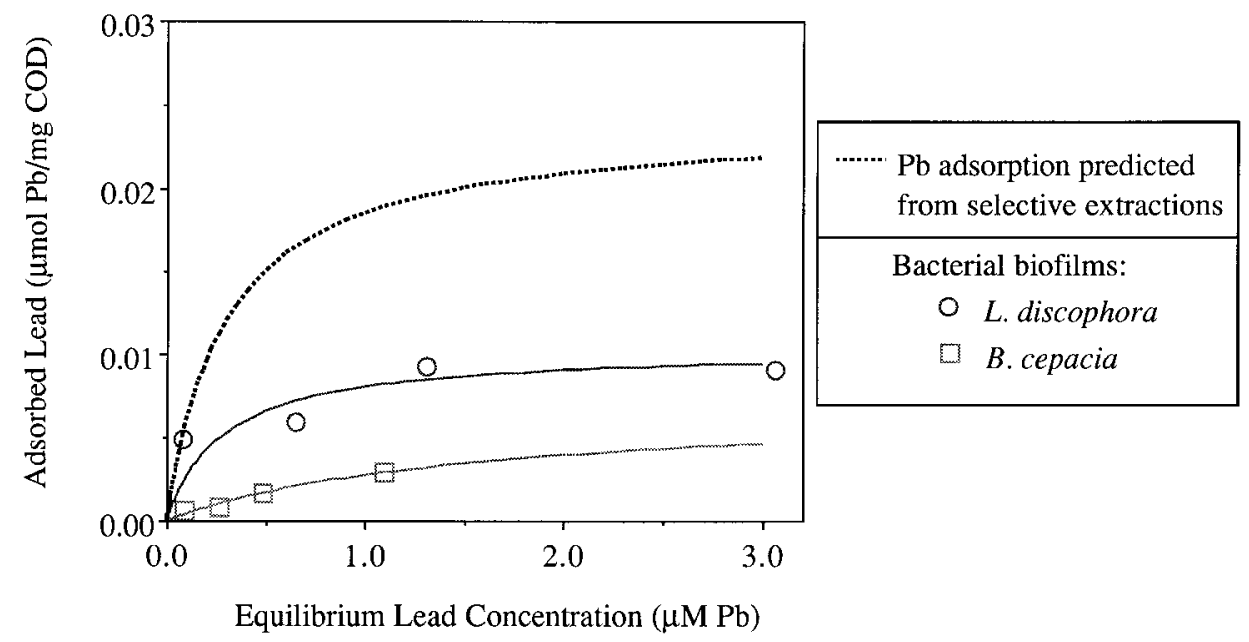

Fig. 9. Comparison of $\mathrm{Pb}$ adsorption to organic material predicted by the non-linear regression analysis of extracted biofilm data to that measured for bacterial biofilms. Adsorption to L. discophora and $B$. cepacia biofilms after Nelson et al. (1999b). 
used in this study can yield realistic estimates of the behavior of adsorptive phases in nature.

Regression analysis of selective extraction data indicated greater $\mathrm{Pb}$ adsorption to $\mathrm{Mn}$ oxides (approx. $2 \times$ ) than that observed for laboratory produced biogenic and abiotic Mn oxides (Fig. 8). Similarly, the selective extraction technique suggests greater (approx. $2 \times$ ) $\mathrm{Pb}$ adsorption by organic materials than that observed for laboratory biofilms produced by two different species of bacteria (Fig. 9). The possible overestimation of $\mathrm{Pb}$ adsorption to the Mn oxide and organic phases may have resulted from performing the regression analysis with consideration of only four adsorbing components (Mn, $\mathrm{Fe}, \mathrm{Al}$ and organic materials). While there could be additional adsorbing phases and/or adsorption mechanisms influencing $\mathrm{Pb}$ and $\mathrm{Cd}$ adsorption in the surface coatings, the regression analysis was forced to converge for only the four components. Thus, any adsorption to other components not considered would be included with adsorption attributed to these four components. This could lead to overestimation of metal adsorption to one or more components. Alternatively, the laboratory surrogates for Mn oxide and organic matter may adsorb less $\mathrm{Pb}$ than their naturally occurring counterparts. However, the excellent agreement of the results for $\mathrm{Pb}$ isotherms on $\mathrm{Fe}$ oxides with estimations previously made using laboratory adsorption isotherms and the reasonable (approx. $2 \times$ ) agreement with other surrogate biofilm components suggests that the contribution of other adsorptive components is likely to have been small.

\section{CONCLUSIONS}

The selective extraction method presented here is unique because of the measurement of trace metal adsorption before and after extraction. This approach avoids the possibility of desorption of trace metals from components other than the target component(s) being extracted. The selective extractions removed target components with efficiencies between 71 and $83 \%$, but significant amounts of metal oxides and organic materials other than the target components were also removed by the extractants (up to $39 \%$ ). Because of this, the amount of $\mathrm{Pb}$ and $\mathrm{Cd}$ adsorption associated with each phase could not be determined by a simple calculation, and a nonlinear regression analysis was used to estimate relative contributions of each surface constituent. This analysis suggested a very strong role of $\mathrm{Mn}$ oxides in controlling $\mathrm{Pb}$ adsorption to the lake biofilms and lesser but significant roles of $\mathrm{Fe}$ oxides and organic material. Adsorption of $\mathrm{Cd}$ to the lake biofilms was dominated by $\mathrm{Fe}$ oxides, with lesser roles of $\mathrm{Mn}$ and $\mathrm{Al}$ oxides and organic material. The results for $\mathrm{Pb}$ agree with previous results of a model based on $\mathrm{Pb}$ adsorption to laboratory surrogate materials for $\mathrm{Mn}, \mathrm{Fe}$ and $\mathrm{Al}$ oxides and defined organic constituents. This agreement suggests that the extraction method presented here provides a reliable estimate of the relative contributions of each component to total trace metal adsorption.

Acknowledgements - This research was supported by the National Science Foundation under Grants BES-97067715 and CHE-9708093. Support for D.D. was provided by a fellowship from the People's Republic of China. We are grateful for the generous assistance of Jery Stedinger and George Casella with the statistical analyses, and to Linda Westlake for the provision of a dock for sampling Cayuga Lake.

\section{REFERENCES}

Anderson B. J. and Jenne E. A. (1970) Free iron and manganese oxide content of reference clays. Soil. Sci. 109(3), 163-169.

APHA (1995) Standard Methods for the Examination of Water and Wastewater, 9th edn. Washington, DC.

Balistrieri L. S. and Murray J. W. (1982) The adsorption of $\mathrm{Cu}, \mathrm{Pb}, \mathrm{Zn}$ and $\mathrm{Cd}$ on geothite from seawater. Geochim. Cosmochim. Acta 46, 1253-1265.

Balistrieri L. S. and Murray J. W. (1983) Metal-solid interactions in the marine environment: estimating apparent equilibrium binding constants. Geochim. Cosmochim. Acta 47, 1091-1098.

Bauer C. F. and Kheboian C. (1986) Metal speciation in aquatic sediments accuracy of selective extraction procedures. Abstr. Pap. Am. Chem. Soc., 191.

Benjamin M. M. and Leckie J. O. (1981) Multiple-site adsorption of $\mathrm{Cd}, \mathrm{Cu}, \mathrm{Zn}$, and $\mathrm{Pb}$ on amorphous iron oxyhydroxide. J. Colloid Interface Sci. 79(1), 209-221.

Campbell P. G. C. and Tessier A. (1991) Biological availability of metals in sediments: analytical approaches. In Heavy Metals in the Environment. Elsevier, Amsterdam, pp. 161-173.

Davis J. A. and Leckie J. O. (1978) Effect of adsorbed complexing ligands on trace metal uptake by hydrous oxides. Environ. Sci. Technol. 12, 1309-1315.

Ghiorse W. C. (1984) Biology of iron- and manganesedepositing bacteria. Ann. Rev. Microbiol. 38, 515-550.

Honeyman B. D. and Santschi P. H. (1988) Metals in aquatic systems. Environ. Sci. Technol. 22(8), 862-871.

Hudson R. J. M. and Morel F. M. M. (1989) Distinguishing between extra- and intracellular iron in marine phytoplankton. Limnol. Oceanogr. 34(6), 11131120.

Jenne E. A. (1968) Controls on $\mathrm{Mn}, \mathrm{Co}, \mathrm{Ni}, \mathrm{Cu}$ and $\mathrm{Zn}$ concentrations in soil and water: the significant role of hydrous $\mathrm{Mn}$ and $\mathrm{Fe}$ oxides. In Trace Inorganics in Water. American Chemical Society, Washington, DC, pp. 337-387.

Krauskopf K. B. (1956) Factors controlling the concentration of thirteen rare metals in seawater. Geochim. Cosmochim. Acta 9, 1-24.

Lindsay W. L. and Norvell W. A. (1978) Development of a DTPA soil test for zinc, iron, manganese and copper. Soil Sci. Soc. Am. J. 42, 421-428.

Lion L. W., Altmann R. S. and Leckie J. O. (1982) Tracemetal adsorption characteristics of estuarine particulate matter: Evaluation of contributions of $\mathrm{Fe} / \mathrm{Mn}$ oxide and organic surface coatings. Environ. Sci. Technol. 16, 660 666.

Luoma S. N. (1989) Can we determine the biological availability of sediment-bound trace elements? Hydrobiologia 176-177, 379-396.

Martin J. M., Nirel P. and Thomas A. J. (1987) 
Sequential extraction techniques: promises and problems. Mar. Chem. 22(2-4), 313-342.

Matijevic E. and Scheiner P. (1978) Ferric hydrous oxide sols. III. Preparation of uniform particles by hydrolysis of $\mathrm{Fe}(\mathrm{III})$-chloride, -nitrate and -perchlorate solutions. J. Colloid Interface Sci. 63(3), 509-524.

Murray J. W. (1974) The surface chemistry of hydrous manganese dioxide . J. Colloid Interface Sci. 46(3), 357371

Murray J. W. (1987) Mechanisms controlling the distribution of trace elements in oceans and lakes. In $A C S$ Advances in Chemistry, Series No. 216, Sources and Fates of Aquatic Pollutants. American Chemical Society, Washington, DC, pp. 153-184.

Nelson Y. M. (1997) Formulation, verification and application of integrated models for trace metal phase distribution in laboratory microcosms and aquatic environments. Ph.D. thesis, Cornell University.

Nelson Y. M., Lion L. W., Ghiorse W. C. and Shuler M. L. (1999a) Production of biogenic $\mathrm{Mn}$ oxides by Leptothrix discophora SS-1 in a chemically defined growth medium and evaluation of their $\mathrm{Pb}$ adsorption characteristics. Appl. Environ. Microbiol. 65(1), 175-180.

Nelson Y. M., Lion L. W., Ghiorse W. C. and Shuler M. L. (1999b) Lead binding to metal oxides and organic phases of natural aquatic biofilms. Limnol. Oceanogr., in press.

Nelson Y. M., Lion L. W., Shuler M. L. and Ghiorse W. C. (1996) Modeling oligotrophic biofilm formation and lead adsorption to biofilm components. Environ. Sci. Technol. 30(6), 2027-2035.

Nelson Y. M., Lo W., Lion L. W., Shuler M. L. and Ghiorse W. C. (1995) Lead distribution in a simulated aquatic environment: effects of bacterial biofilms and iron oxide. Water Res. 29(8), 1934-1944.

Ramsay B. J., deTremblay M. and Chavarie C. (1988) A method for the quantification of bacterial protein in the presence of jarosite. Geomicrobiol. J. 6, 171-177.

Salim R. (1983) Adsorption of lead on the suspended particles of river water. Water Res. 17, 423-429.
Santschi P. H., Lenhart J. J. and Honeyman B. D. (1997) Heterogeneous processes affecting trace contaminant distribution in estuaries: the role of natural organic matter. Mar. Chem. 58(1-2), 99-125.

Sigg L. (1985) Metal transfer mechanisms in lakes: the role of settling particles. In Chemical Processes in Lakes. John Wiley, New York, pp. 283-310.

Tessier A. and Campbell P. G. C. (1987) Partitioning of trace metals in sediments relationships with bioavailability. Hydrobiologia 149, 43-52.

Tessier A., Campbell P. G. C. and Bisson M. (1979) Sequential extraction procedure for the speciation of particulate trace metals. Anal. Chem. 51, 844-850.

Tessier A., Fortin D., Belzile N., DeVitre R. R. and Leppard G. G. (1996) Metal sorption to diagenetic iron and manganese oxyhydroxides and associated organic matter: narrowing the gap between field and laboratory measurements. Geochim. Cosmochim. Acta 60(3), 387404.

Tipping E. and Cooke D. (1982) The effects of adsorbed humic substances on the surface charge of geothite in freshwaters. Geochim. Cosmochim. Acta 46, 75-80.

Turekian K. K. (1977) The fate of metals in the oceans. Geochim. Cosmochim. Acta 41, 1139-1144.

Vuceta J. and Morgan J. J. (1978) Chemical modeling of trace metals in fresh waters: role of complexation and adsorption. Environ. Sci. Technol. 12(12), 1302-1308.

Westall J. C., Zachary J. L. and Morel F. M. M. (1976) MINEQL, a computer program for the calculation of chemical equilibrium composition of aqueous systems. Tech. Note 18. Department of Civil Engr. Mass Inst. of Tech. Cambridge, MA.

Young L. B., Dutton M. and Pick F. R. (1992) Contrasting two methods for determining trace metal partitioning in oxidized lake sediments. Biogeochemistry 17(3), 205-219.

Young L. B. and Harvey H. H. (1992) The relative importance of manganese and iron oxides and organic matter in the sorption of trace metals by surficial lake sediments. Geochim. Cosmochim. Acta 56, 1175-1186. 